\title{
RASTROS DE ARTESANIA NA PESQUISA EM EDUCAÇÃO
}

\author{
Cíntia Langie ${ }^{1}$ \\ Carla Gonçalves Rodrigues ${ }^{2}$
}

Resumo: Como valorizar a experiência com a arte nos trabalhos acadêmicos? Partindo dessa inquietação inicial, o texto busca tracejar sete rastros de aproximação entre arte e pesquisa em educação, em vias de arejar a escrita acadêmica com procedimentos artesanais advindos de processos criativos do cinema e da literatura. A justificativa para tal proposta está na valorização do atravessamento entre arte e ciência na produção e criação de sentidos e de conhecimentos em nosso tempo hoje, táo plural e dinâmico.

Palavras-chave: Arte. Educação. Pesquisa. Processo. Estilo.

\section{RASTROS DE ARTESANÍA NA INVESTIGACIÓN EN EDUCACIÓN}

Resumen: ¿Cómo valorar la experiencia con el arte en los trabajos académicos? A partir de esa inquietud inicial, nuestro texto busca trazar siete rastros de acercamiento entre arte e investigación en educación, en vías de ventilar la escritura académica con procedimientos artesanales provenientes de procesos creativos del cine y de la literatura. La justificación para tal propuesta está en la valorización del atravesamiento entre arte y ciencia en la producción y creación de sentidos y de conocimientos en nuestro tiempo hoy, tan plural y dinámico.

Palabras clave: Arte. Educación. Investigación. Proceso. Estilo.

\section{TRACES OF ARTESANIA IN RESEARCH IN EDUCATION}

\begin{abstract}
How to value the experience with art in academic works? Starting from this initial uneasiness, the text seeks to trace seven traces of the approximation between art and research in education, in the process of airing academic writing with artisanal procedures derived from creative processes of cinema and literature. The justification for such a proposal lies in valuing the crossing between art and science in the production and creation of meanings and knowledge in our time today, so plural and dynamic.
\end{abstract}

Keywords: Art. Education. Search. Process. Style.

1 Mestre em Comunicação Social pela PUCRS. Doutoranda em Educação PPGE-UFPel. Professora do curso de Cinema e Audiovisual da UFPel.

2 Pós-Doutora em Educação UFRGS. Professora do Programa de Pós-Graduação em Educação da UFPel. 
Ideias não nascem prontas.

DELEUZE $^{3}$

\section{Introduçáo}

Não costumeiramente conseguimos saber, nem pensamos, ao ver uma obra de arte, que movimento de produção está por traz dela. De certo modo, nem lembramos que alguém, em dadas condições, em algum tempo, a produziu. Talvez nunca possamos saber ao certo quais lampejos de pensamento fazem os artistas enxergarem a sombra daquilo que virará a ser obra. E enquanto público, somos privados de saber quais relações estes encontram nas forças heterogêneas de que se valem para a criação.

Ao mesmo tempo, somos espectadores desde a infância: uma vez que nascemos olhamos o mundo. Desde muito cedo, nesse mundo, somos expostos a obras de diferentes naturezas, sobretudo audiovisuais. Se não pudéssemos viver tantas outras vidas, a partir do cinema, da literatura, das letras de música... dificilmente conseguiríamos entender a nossa própria vida. Logo, ser espectador é um modo de expandir o fluxo da existência.

Como valorizar, nas pesquisas acadêmicas, a experiência de espectador que portamos ao longo desses anos? Como entender que uma obra de arte expressa não só resultados ou conteúdos, mas maneiras de moldar o caos que nos cerca? Como aprender, com os artistas, a criarmos pesquisas em educação mais conectadas com nosso tempo hoje, tão plural, tão dinâmico?

No desejo de atravessar a ciência pela arte, a proposta deste artigo centra-se em apresentar sete pistas para propostas de arejamento de trabalhos acadêmicos, acreditando que tanto a arte, como a escrita de uma pesquisa, são modos de artesania. É preciso trabalhar, pensar, desacomodar: uma ideia não nasce pronta. O fazer artísticos não se reduz a inspiração, pois não é de ideias que uma poesia é feita - lembra Valery - mas de palavras: construção de pensamento.

Materializar as ideias em palavras, criar um plano de consistência (DELEUZE; GUATTARI, 2010), sentir e escrever: tarefa que solicita não só um corpo sensível, como também engajado e disposto a se reinventar. A ideia de traduzir em pistas esse movimento, não se trata de aproximação ao formato de manual prescritivo, mas configura-se apenas como uma vontade de compartilhar com o leitor rastros de pensamento de duas pesquisadoras que agenciam arte, filosofia e educação.

\section{O outro}

Se vemos a arte como fabulação que cria novos possíveis no mundo (DELEUZE; GUATTARI, 2010), tal processo de invenção passa, inevitavelmente, por uma questão ética: quais as relações de alteridade implícitas na criação?

3 1997, p. 54 
No cinema documentário isso se expressa na questão como gravar e editar o outro? Como construir, no filme, um outro que emerge da relação entre documentado e documentarista? A questão da alteridade, aqui, é entendida como um jogo (COMOLLI, 2008). Alteridade não como um modo de ver o outro, pois o "outro" não existe em si, é sempre resultado de uma relação, um devir, uma fronteira tênue entre pesquisador e pesquisado - já que ambos se dissolvem na relação transversal que a arte e a pesquisa solicitam.

Falar sobre essa questão pode aparelhar pesquisadores cujos métodos de investigação pressuponham a realização de entrevistas, bem como pesquisa de observação ou realização de grupos focais. $\mathrm{O}$ ato de escrever, nesses casos, envolve um outro: aqueles que entrevisto ou que observo. Assim, tanto um filme, como um texto de pesquisa, são relações que só existem na fricção com o outro, no encontro. De modo bastante geral e inicial, envolvimento e conhecimento do tema podem indicar estratégias para encontrar uma ética particular.

Quando o indivíduo está fazendo a obra - seja artista ou pesquisador - ele se envolve de determinada forma, e vê seu objeto de determinado modo. Buscar ser honesto com essa relação criada no processo, é um modo ético de agir na construção da expressão. Mas, talvez só isso não seja suficiente e para alongar um pouco mais o debate pensaremos ao lado do cineasta brasileiro João Moreira Salles.

Como se filma o outro? Essa é uma questão central para o documentário Santiago (2007), obra na qual Moreira Salles problematiza suas escolhas estéticas. O cineasta investiga sua própria transformação, durante a realização do filme, compartilhando com o espectador a experiência de construção da obra.

Imagem 1. Cena do documentário Santiago, 2007.

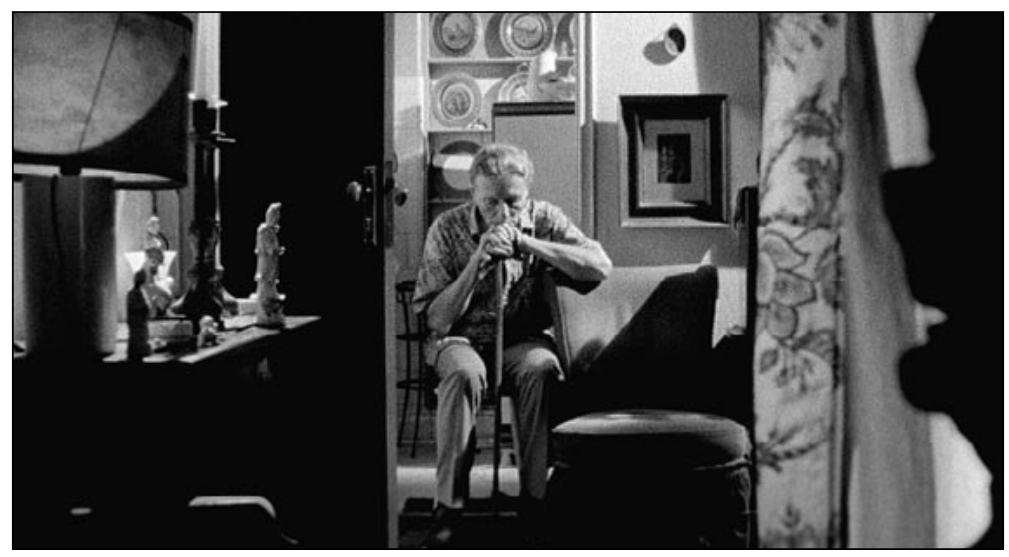

Fonte: http://www.alpharrabio.com.br.

O documentário conta a história de Santiago, mordomo da família de Moreira Salles e figura bastante presente em sua infância. O fato é que o diretor não ficou satisfeito com a primeira versão que fez, em 1992, e desistiu do filme. Porém, 13 anos depois, em 2005, ele retoma o material e faz uma nova obra, buscando avaliar 
uma certa "ausência" de alteridade em determinados momentos do processo, quando ele - o "patrão" -, havia sido autoritário ou mesmo insensível com seu objeto documentado - o mordomo.

Em 2007 ele lança o longa-metragem, com uma voz em off questionando sua atuação na primeira tentativa. O resultado é um filme criativo, que se torna também uma aula de documentário, pois oferece uma experiência de aprendizado. Compartilha com quem vê a obra meandros internos da maquinaria cinematográfica. Em um momento, Moreira Salles diz: "é difícil saber até aonde íamos em busca do quadro perfeito, da fala perfeita" . Assim, não só evidencia a relação de poder implícita no ato de gravar o outro, como expõe ao espectador particularidades do dispositivo do cinema.

O diretor, nessa experiência, busca, sobretudo, ser honesto frente ao seu objeto documentado. Essa fronteira tênue entre criar e expor o outro, também ocorre nas pesquisas acadêmicas, quando nos questionamos de que forma vamos inventar nossos objetos no texto final. Moreira Salles coloca em marcha uma espécie de autocrítica, talvez buscando evidenciar que toda construção é fabulação, pois parte de uma atitude de inventar um terceiro, que não é nem autor nem objeto, mas um virtual que surge na relação.

Um dos aprendizados que se pode tirar da experiência de espectador, com esse filme, é a importância da atitude de escuta: entregar-se ao entrevistado para saber mais que apenas perguntas sobre a temática. Querer também saber coisas banais dele, assumindo uma atitude de maior generosidade frente ao desafio de conhecer o outro, e frente à própria vida enquanto pulsar: matéria de complexidade e diferença.

\section{Real ficcionado}

"O real precisa ser ficcionado para ser pensado", diz Jacques Rancière (2009, p. 58), filósofo francês autor de diversas obras que imbricam a dimensão política no fazer artístico. Tanto a política quanto a arte constroem ficções, afirma ele, operam rearranjos de imagens e palavras, interferem nas relações entre o que se vê e o que se diz. E nesse sentido não deveríamos opor ficção à realidade, já que testemunho e ficção pertencem ao mesmo regime de sentido, segundo o filósofo.

Os artistas, para Deleuze (2005), não buscam uma verossimilhança com real, não buscam atingir a verdade do mundo, mas talvez a verdade do cinema. "O artista é criador de verdade, pois a verdade não tem de ser alcançada, encontrada nem reproduzida, ela deve ser criada. Não há outra verdade senão a criação do novo" (DELEUZE, 2005, p. 178). A arte, assim, é criadora da verdade, ali mesmo onde o falso atinge sua potência última: fabulação. O cinema inventa expressões, imagens, mas é a vida que jorra.

4 Trecho do OFF do filme Santiago (João Moreira Salles, 2007). 
Para Deleuze, fabular é destruir modelos de verdade para se tornar um criador (DELEUZE, 2005, p. 183). A isso, o filósofo chamará de potência do falso. Fabular também se relaciona com a noção de minoria, a ideia de um povo que falta, a invenção de uma comunidade. Fabular é traçar um plano e a partir desse ato criar outras verdades.

Nessa mesma linha de pensamento, o cineasta iraniano Abbas Kiarostami (2013) declara que algumas mentiras refletem melhor a realidade interior do que supostas verdades: artista é aquele que sabe criar belas mentiras. Os documentários mostram bem isso, pois não é na busca de uma pretensa fidelidade com o que de fato teria ocorrido que pode emergir a força do filme, e sim valendo-se do dispositivo como uma potência fabuladora, que desestabiliza as regras tradicionais de expressão audiovisual.

Eduardo Coutinho, documentarista brasileiro, trabalhou essa questão de forma inspiradora ao longo de sua carreira. A força do longa-metragem Jogo de cena (2007), por exemplo, está na relação entre realidade e fabulação. Nesse filme, mulheres não-atrizes são entrevistadas para falarem de suas vidas. Elas podem falar o que de mais verdadeiro desejem, mesmo que tudo que falem seja fabulado. Não importa se aconteceu ou não. Aconteceu na hora da entrevista, e esse é o fato cinematográfico. Na pesquisa, também há ocorrência de acontecimentos, pois pensamentos e ideias muitas vezes existem por conta da situação posta, e não da realidade descrita ou analisada. Depois, no documentário em questão, Coutinho convida atrizes para "re-encenarem" os depoimentos das mulheres, e o resultado é um filme em que a zona de indiscernibilidade entre real e ficção faz com que a força da vida, ali, venha à tona.

Imagem 2. Cena do documentário Jogo de cena, 2007.

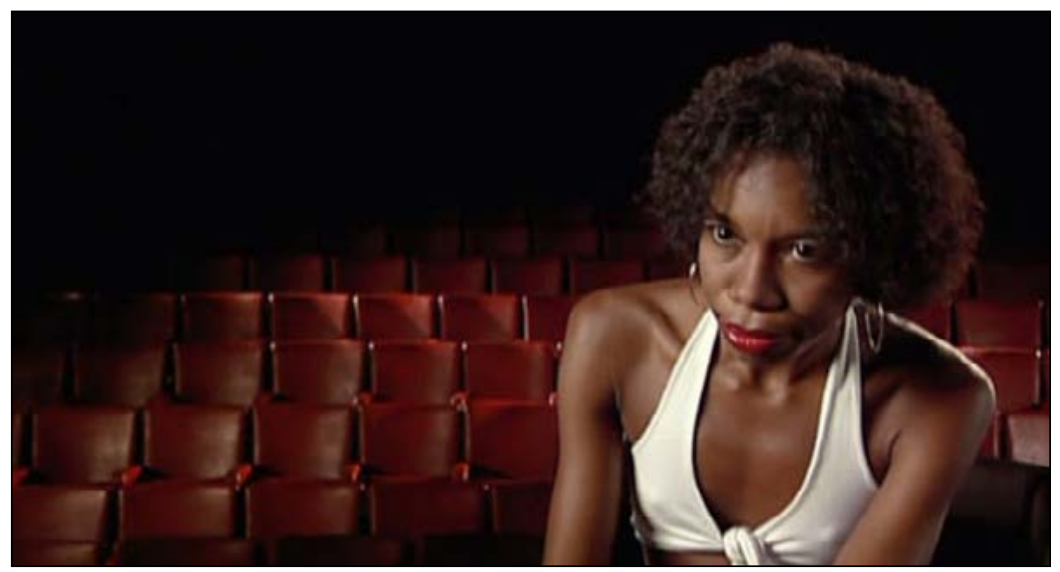

Fonte: http://www.adorocinema.com.

Por vezes, não entendemos qual das mulheres está mais emocionada: a que de fato contou a história (supostamente tendo vivido a experiência narrada) ou aquela que está ali interpretando - o filme, assim, nos faz sentir a proximidade 
entre a arte e a vida. Em algumas cenas, não conseguimos saber qual personagem é a atriz e qual a "verdadeira", já que a montagem deixa isso em aberto, e ambas transparecem naturalidade na fala.

Essa forma de não entregar respostas, faz com que o espectador participe do jogo, tire suas próprias conclusões, convocando o movimento do pensamento. Foi um modo encontrado por Coutinho para fabular a experiência de algumas mulheres, que ali, no filme, são circunstâncias para expressar a complexidade da vida. O diretor não busca explicar, nem desvendar segredos, mas deixar que o jogo se dê na cena, na montagem, na criação, na mente do público.

Transpondo para o universo acadêmico, qual a verdade de nossas pesquisas? Qual o modo de ficcionar o nosso real que permite que o pensemos, que entremos nele não pela armadilha da explicação ou redução, mas dando vida ao objeto? Como evitar apenas imitar a vida como ela é tentando copiar aquilo que é estabelecido, que está no senso comum? O senso comum nunca é a vida em sua complexidade, e sim um reducionismo aos pontos canônicos daquilo que é visível, daquilo que ocorre na maioria das vezes. Como nossas pesquisas podem contribuir para ir além disso?

\section{Criar um estilo}

A escrita é como música: cria um universo, embala, imprimi um ritmo, dispara sensações. Inventar formas originais de expressão é encarar a escrita como invenção. Moldar os verbos, como o artesão molda a argila, vendo prazer na construção frasal, buscando sair do modo óbvio e correto de usar as palavras, colocando uma alma no ato de escrever: eis maneiras de dar vida à obra.

Para Peter Brook, diretor de teatro e cinema britânico, a arte deve contar com uma energia vital que faça o outro se envolver. Cada frase de nossos textos, como cada cena de um filme, ou o trecho de uma canção, tem que encontrar o seu caminho, trazendo energia ao jogo da fruição. "Todo o problema reside em tentar entender se, a cada momento, na escrita ou na performance, existe uma fagulha, a pequena chama que incendeia e confere intensidade aquele momento destilado, comprimido" (BROOK, 2016, p. 13-14). A fagulha, para o autor, é aquilo que importa, aquilo que mantém o leitor ou espectador aceso diante da obra. É, pois, um problema artístico que pressupõe encontrar intensidade a cada nova sentença.

Desse modo, como tecer variações para contar sua história? Seja na literatura, no cinema ou na pesquisa acadêmica, a escrita solicita um corpo vibrátil (ROLNIK, 2014), uma sensibilidade para compreender o objeto e inventar - junto com ele, na relação - um modo peculiar de apresentá-lo ao mundo. Encontrar uma forma para nossas ideias é criar uma maneira própria de investigar, sem querer separar forma de conteúdo e forma de expressão, pois existem em simbiose. Não seria, então, urgente, deixar a pesquisa falar mais, produzindo modelos de escrita que estejam em sintonia com o objeto? 
O fenômeno político, o fenômeno social, só ganham sua importância artística quando expressos através de uma obra de arte que esteja colocada numa perspectiva estética. Ou seja, a bela frase de Brecht que diz 'para novas ideias, novas formas'. Não há outra saída (GLAUBER ROCHA, 1981, p. 138).

Cada tema, cada história, solicita um modo de escrita singular. Em Kafka, por uma literatura menor (1977), Deleuze e Guattari mostram que o potencial inovador de Kafka, enquanto autor, está na criação de variações na língua dominante. Desse modo, a escrita está na esfera política. A arte - e a pesquisa - podem fazer "gaguejar a língua corrente, ou tremer, ou gritar, ou mesmo cantar: é o estilo, o 'tom', a linguagem das sensações ou a língua estrangeira na língua" (DELEUZE; GUATTARI, 2010, p. 208). A arte é capaz de torcer a narrativa, maquinar, fazer novas conexões, traçar circuitos diferentes: abrindo brechas na língua padrão e expandindo suas possibilidades.

Uma literatura menor, por exemplo, seria o que qualifica as condições revolucionárias de uma escrita no seio daquilo que chamamos de grande literatura, ou literatura hegemônica. É, pois, resistência. "Estar em sua própria língua como estrangeiro" (DELEUZE; GUATTARI, 1977, p. 40-41). Tornar-se menor é pôr a variar a língua e fazer do seu jeito, uma maneira singular, sem querer imitar ou copiar o modo estabelecido. Diz respeito à fabricação de funções de linguagem diferentes, ventila o que pode e o que não pode ser dito, e as maneiras de dizer.

Pressupõe tecer um estilo, também, a tarefa de engendrar ritmo nas ideias, colocando as palavras em movimento. Para o cineasta alemão Wim Wenders, escrever é como montar filmes: assiste-se ao material inúmeras vezes para destacar e moldar aquilo que tem potência de dizer algo, ou que desperta sensações.

O desafio é escrever-como-montar, de modo que elas se ponham em movimento - como no cinema. A escrita, como a edição de um filme, gera um determinado fluxo (WENDERS, 2016, p. 17). Escrever como esculpir. Trabalhar, com rigor, para tirar excessos. Exercício de montagem: ir colocando tudo que se tem, mesmo de forma bagunçada, caótica. Depois, com rigor, há que se ler com distanciamento, para ir lapidando, afinando.

Assim, um dos potenciais da criação está na montagem: fazer cruzamentos, fantasiar tramas, criar vizinhanças. A ciência pressupõe pôr em relação e, portanto, analisar - em pesquisas acadêmicas - trata-se de cruzar teoria com empiria, colocando matérias distintas e heterogêneas para dialogar.

A potência está então na própria experimentação: somos mais artesãos que descobridores de "verdades encobertas". Vale mais perguntar do que ter pressa de responder. Deixar, desse modo, o texto mais leve, permitindo que o leitor continue pensando sobre aquilo, depois das linhas acabarem, sem entregar conclusões fechadas. Tentar escrever com poesia, evitando a moral da fábula: eis um desafio para nós, pesquisadores. 


\section{Criar é agenciar}

Para Deleuze e Guattari (1977), a literatura de Kafka é puro agenciamento. Isto é, sua obra é feita de uma maquinaria em que forma de conteúdo e forma de expressão se imbricam, andam juntas, enfim, se agenciam. $O$ tema dos livros de Kakfa, o modo como a sua escrita se manifesta, seus elementos, seu estilo, seu modo de escrever: são forças que se retroalimentam. "Um escritor não é um homem escritor, é um homem político, e é um homem máquina, e é um homem experimental “ (DELEUZE, GUATTARI, 1977, p. 13). Isso porque, para Deleuze e Guattari, tudo está em conexão no campo social. Um autor, como máquina desejante, é apenas parte - uma peça, uma das engrenagens - de um agenciamento social.

"O essencial em Kafka é que a máquina, o enunciado e o desejo façam parte de um único e mesmo agenciamento, que dá ao romance seu motor" (DELEUZE, GUATTARI, 1977, 120). Portanto, os artistas não criam nada sozinhos. Há algo além de uma vontade pessoal: a interferência do socius, o entendimento de um espírito do tempo, relações de forças. Existem condições de possibilidades, modos de manejar dispositivos que, na mistura, fazem emergir faíscas de criação, criam motores.

Bergala (2004) diz que Kiarostami é o cineasta do agenciamento, em uma outra concepção do termo, mas que também se torna interessante para pensar em jornadas criativas. O que o diretor iraniano faz, diz Bergala, é ligar um personagem ao outro para que um deles saia da inércia, ou se desterritorialize, para usarmos uma linguagem deleuze-guattariana. Em nossa leitura, podemos dizer que em um filme, ou em uma pesquisa, é o criador que se agencia com seu objeto para, assim, criar um outro agenciamento que é a obra. Autor se enrola no personagem, agencia com ele, interage - se acoplam, se complementam, andam juntos para que se possa dizer alguma coisa, já que o autor é levado a dizer não pela sua vontade pessoal, mas pela relação, pelo agenciamento.

Agenciamento se efetua quando um filme, por exemplo, usa uma linguagem, uma forma de expressão, que engancha com o tema. No documentário Paulinho da Viola - Meu tempo é hoje (Izabel Jaguaribe, 2003) o filme agência a vida do músico - sua relação com o tempo - e a linguagem audiovisual: pois esta acompanha o objeto, no caso Paulinho da Viola, no cotidiano, sem pressa, criando um estilo de narrar que está em compasso com o espírito do personagem. 
Imagem 3. Cena do filme Paulinho da Viola, meu tempo é hoje, 2003

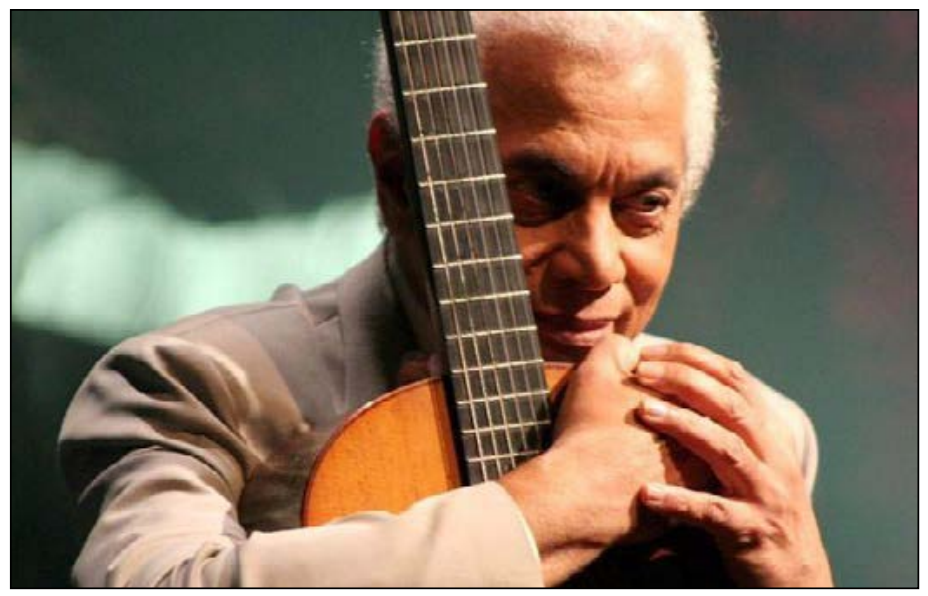

Fonte: http://pe.olx.com.br.

Pensemos agora no documentário Pina (2011), pois há ali um agenciamento. Wim Wenders conhece Pina Bauch enquanto espectador, encanta-se pelo trabalho de dança-teatro da artista na plateia de um de seus espetáculos. Depois, ambos ficam amigos e passam a articular a ideia de um dia fazerem um filme juntos. A cada ano que passava, Wenders desejava ainda mais gravar um documentário sobre o trabalho de Pina.

Porém, ele achava que a "forma filme" era insuficiente para retratar a beleza dos espetáculos da coreógrafa. Achava que o cinema, com o achatamento das imagens em duas dimensões, seria incapaz de transmitir a força daquele movimento. Somente quando surgiu a possibilidade do 3-D no universo audiovisual é que Wenders vislumbrou uma perspectiva para filmar o espetáculo de Pina Bauch: imbricando a forma de expressão na forma de conteúdo.

O agenciamento, neste caso, vai além da técnica. Pina tinha uma maneira peculiar de ensaiar: costumava lançar apenas uma palavra a seus bailarinos e pedia que eles expressassem corporalmente o sentimento que tal palavra provocava.

Lo hizo con un método absolutamente único. Un científico diria: con un nuevo diseno experimental.

Lo que hizo en los ensayos, durante semanas y meses enteros, fue ir planteándoles preguntas a los bailarines. Les daba conceptos y auscultaba sus asociaciones.

Los bailarines no podían responder con palabras, debían servirse exclusivamente de su recurso más primário, de sus movimientos, de sus gestos, de sus danzas. (WENDERS, 2016, p. 118). 
No documentário, Wenders também explora isso, mas de um outro jeito. Agenciando-se com o objeto - a "essência" Pina - Wenders inova, cria uma língua estrangeira no modo hegemônico de realizar entrevistas no cinema. No filme, os bailarinos não aparecem falando, e sim ouvindo ou dançando. Wenders, desse jeito, remete ao próprio fazer artístico de Pina, ao utilizar somente a voz do entrevistado e não sua imagem correspondente. Valoriza o depoimento com um estilo criado na mistura com o objeto: os bailarinos aparecem ouvindo, contemplativos, como se estivem pensando em Pina - que havia falecido pouco antes de começarem as gravações.

\section{O espaço para o imprevisível}

Uma outra pista, para a criação, apreendida de processos artísticos, é se deixar levar por aquilo que não programamos, aquilo que talvez nem estivesse em nossa mira: olhar para o que não é obvio. "Tento tornar visível o que só é invisível por estar muito na superfície das coisas» (FOUCAULT, 2008, p. 146). Quando buscamos desvendar mistérios, acabamos esquecendo de valorizar, também, aquilo que, de tão obvio, nos passa despercebido. Não só dar conta de perceber coisas que estavam lá, e que não esperávamos encontrar, como olhar para elas de forma a reinventar as significações redutoras do senso comum, preenchendo de novos sentidos os nossos temas de pesquisa.

Kiarostami tem algo a nos ensinar nesse sentido. Em seu livro Duas ou três coisas que sei de mim (2013) ele conta que não costuma entregar os roteiros completos a seus atores, pensando em obter mais naturalidade das encenações. Dito de outro modo, o diretor deixa o ator conhecer somente suas próprias falas e não os diálogos dos demais personagens, para que, na gravação, possa haver lugar para o inesperado. $O$ diretor também não utiliza cronogramas fixos, prefere gravar na ordem que for melhor aos atores, quando estes estão dispostos, sem impor um produtivismo, já que se trata de arte. Ambas estratégias de Kiarostami são formas de encontrar aquilo que pode emergir da espontaneidade - é a experiência que gera sua marca de simplicidade. Assim, o diretor dá espaço para que o imprevisível possa emitir faíscas de expressão, escutando e olhando também para aquilo que ocorre durante e no meio da própria realização, sem programar tudo. 
Imagem 4. Cena de E a vida continua, 1992

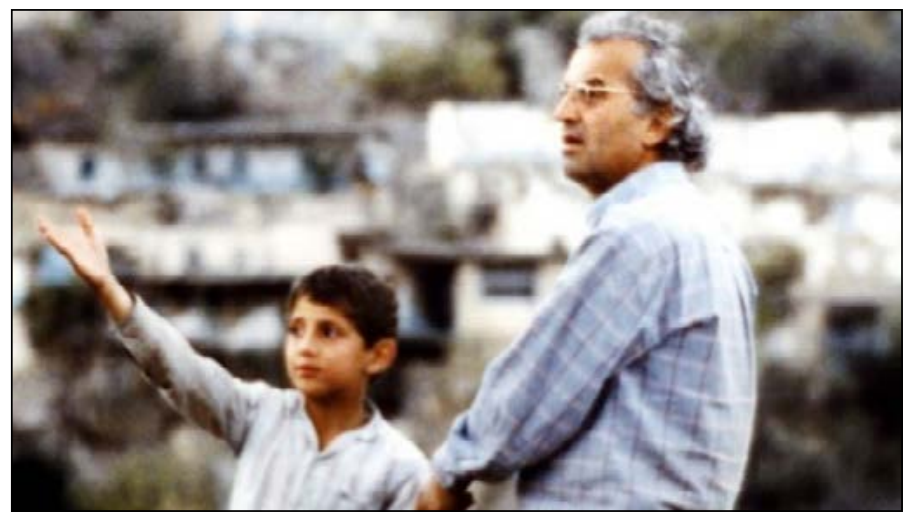

Fonte: http://www.cineplayers.com.

Em 1990 - conta Kiarostami (2013) - um terremoto devastou a região em que ele havia anteriormente filmado Onde fica a casa do men amigo? (1987), e 95\% da população havia morrido sob os escombros. $O$ diretor investe em uma nova incursão para aquela região, a fim de procurar seus dois atores mirins do filme anterior. Diz que havia uma certa exaltação na mídia em torno do fato, já que as duas crianças do filme tinham se tornado símbolos da região.

Eu mesmo, logo que cheguei às zonas abaladas, tive a sensação de que a aldeia havia se tornado apenas um monte de escombros. Depois comecei a perceber alguns detalhes: algumas pessoas lavavam os tapetes e as cobertas estendendoos para secar as árvores; uma senhora tentava, sozinha, retirar um tapete debaixo de quatro metros de escombros [...] Vi muitas cenas desse gênero, que testemunhavam o desejo dos habitantes de sobreviver (KIAROSTAMI, 2023, p. 234).

Apesar de haver uma ideia inicial, o cineasta acaba fazendo um outro filme, pois olha para aquele lugar não com o ponto de vista mais esperado ou previamente definido - como destruição, tristeza -, mas se deixa levar pelo imprevisível e, com escuta e sensibilidade, encontra ali algo além da tragédia, enxerga a vida que resiste, fabula: cria o novo. Assim nasce o longa E a vida continua (1992).

Se, em Onde fica a casa do meu amigo?, o garoto não encontra a casa do colega, mas em troca, ganha a sua amizade, em $E$ a vida continua os dois personagens à procura dos dois meninos não os encontram, mas acabam por descobrir algo mais importante, ou seja, que a vida, de qualquer maneira, continua (KIAROSTAMI, 2013, p. 238).

Como nos colocarmos atentos, em nossas pesquisas, ao que não esperávamos encontrar? Mais que isso, como deixar de lado algumas ideias clichês, livrando-nos das expectativas e passando a olhar para nossa temática de um outro ponto de vista? 


\title{
Criar vazios e apostar na simplicidade
}

Gosto quando o espectador estica o pescoço para ver o que não está lá, diz Kiarostami. O espaço aberto, rarefeito, convida o outro a participar da criação de sentido. O cinema de Kiarostami faz ver sem mostrar. Já uma obra que mostra tudo, vira pedagógica demais, saturada, cheia, explicativa: é, pois, chamada por ele de pornográfica (2013, p. 184).

\begin{abstract}
Não suporto o cinema narrativo. Abandono a sala. Quanto mais se esforça por contar, e quanto mais sucesso tem nisso, maior a minha resistência. A única maneira de prefigurarem um cinema novo reside em um maior respeito pelo papel desempenhado pelo espectador (KIAROSTAMI, 2013, p. 182).
\end{abstract}

No cinema, há o extracampo: aquilo que não está na tela, mas que está lá de alguma forma. Pode ser o uso de um som ou de um olhar para fora do quadro. Algo que não aparece na imagem, mas é sugerido pelos elementos da cena. Isso estimula a imaginação do espectador. Em muitas cenas de Kiarostami, quem fala nem sempre aparece na tela. Isso faz do personagem presente, sem saturar a narrativa.

Buscar uma lógica rarefeita, aberta, esvaziada - no cinema, isso ocorre quando o filme deixa buracos, introduz vazios e espaços em branco, rarefaz a imagem. "Suprimir dela muitas coisas que foram acrescentadas para nos fazer crer que víamos tudo" (DELEUZE, 2005, p. 32). Ao explorar o movimento criativo, Deleuze e Guattari (2010) insistem no espaço em branco, um quê de silêncio, abstração, ambiguidade, que vão chamar de vazios. "Os blocos precisam de bolsões de ar e de vazio, pois mesmo o vazio é uma sensação, toda sensação se compõe com o vazio" (DELEUZE; GUATTARI, 2010, p. 195). Assim, a criação no cinema pode acontecer quando um filme faz vir diante do público não a semelhança, mas a pura sensação.

Não se trata de buscar uma correspondência entre o que é visível, dizível e o que o público deve apreender. Ao contrário, trata-se de criar fissuras, suspensão, convocando o corpo para agir, participar da obra: permitir o encontro, suscitar o pensamento. O que conta é o espaço oco entre duas imagens, esse interstício, um silêncio que obriga o pensamento a preencher a lacuna. "Um cérebro que pisca, e re-encadeia ou faz anéis, assim é o cinema” (DELEUZE, 2005, p. 256-257). Como fazer isso em nossas escritas?

Podemos ir permeando o texto com momentos de reticências, evitando certezas, evitando definições e classificações estanques. Deixar buracos, fazer ver sem mostrar. Podemos investir em uma montagem mais solta em alguns trechos, sem querer relacionar todos os parágrafos, ideias, capítulos, deixando conexões para serem feitas pelo leitor.

Dando força a esse argumento, Rancière sugere a emancipação no local da explicação. A explicação - em uma aula, em um texto - pode ser embrutecedora, pois impõe um ponto de vista como sendo soberano. Já emancipar é acreditar na igualdade das competências. Segundo Rancière, nenhum livro, nenhum filme, nenhuma obra de arte precisa de alguém que a explique. "Quem emancipa não tem 
que se preocupar com aquilo que o emancipado deve aprender. Ele aprenderá o que quiser, nada, talvez" (RANCIÈRE, 2005, p. 37). Desse modo, pensar em uma atitude emancipadora é buscar fugir da extrema explicação, do didático em excesso.

A escritora brasileira Clarice Lispector inventa personagens que se questionam a si mesmas porque as coisas são sempre iguais, mas Clarice não dá as respostas. "Mas já que se há de escrever, que ao menos não se esmaguem com palavras as entrelinhas", diz a autora. Ela cria seres que têm descobertas, mas que não explicam isso ao público. Desse jeito, a obra da autora questiona sem prescrever. Clarice mistura o vivido na arte. Inventa uma linguagem que se desnuda e que faz conexões não por lógica, mas faz roçar forças heterogêneas. Fala das coisas como nem sempre estamos acostumados a ler. Sua escrita, muitas vezes, apresenta uma cena, indicando que a história será levada para tal lugar. Sem aviso prévio, ela apresenta uma frase inesperada, que como um golpe nos faz pensar, nos leva para outro lado, para fora de nós mesmos. Assim, esse tipo de leitura nos permite acessar outro tempo: sair por instantes que seja do cronológico e se permitir viver o tempo da intensidade.

\section{Imagem 5. Escritora Clarice Lispector.}

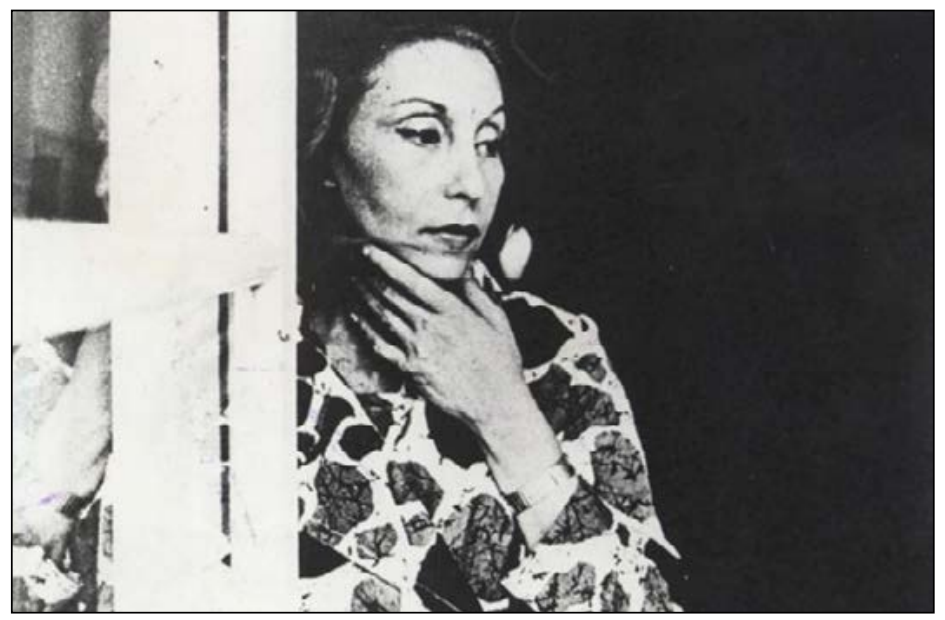

Fonte: http:/ /www.elfikurten.com.br

Outra marca gestual da escrita de Clarice é a valorização das coisas simples da vida, inserindo temáticas e cenas do cotidiano em seus escritos. O cinema de Kiarostami também comporta esse gesto criativo. Em uma situação de aula, o diretor iraniano foi indagado por um de seus alunos: esse alegava que somente pelo fato de Kiarostami ser conhecido enquanto artista é que ele poderia lançar filmes de tamanha simplicidade, como Dę (2002), por exemplo. O cineasta, então, responde: "Fazer coisas simples exige uma boa dose de experiência. E, além disso, é preciso entender que simplicidade não é sinônimo de facilidade" (KIAROSTAMI, 2013, p. 263). A simplicidade exige experiência. 
O simples traz em si uma riqueza. Os temas de nossas pesquisas não precisam ser inéditos ou parecerem "complicados". Podem ser cotidianos, mas levados a sério por nós, na escrita, com boa dose de experiência na temática. Tornar algo simples é fazer com que aquilo com o qual escolhemos lidar seja observado com a naturalidade que uma pesquisa exige e com a singularidade que a temática solicita. Em muitos momentos, a verdade do objeto advém de um modo simples de apresenta-lo. Modo este que será pensado no encontro, na fricção entre autor e objeto. Além disso, aprendemos com Clarice e com Kiarostami que nossa escrita pode ser permeada pela simplicidade dos fatos da vida, e isso não quer dizer menor trabalho, ou algo de mais primitivo.

\section{Ética do compartilhamento de processos}

Alguns artistas ocupam-se em cuidar, na ação de lapidar a obra, para não limpar demais a escrita e deixá-la asséptica, ou seja, optam por deixar transparecer, no resultado final, as dúvidas, os erros e as transformações do processo. Faz parte de uma postura ética, também, contar o que deu errado, dividir fraquezas, assumir as dificuldades - compartilhar singularidades da construção de conhecimento, da composição criativa. Deixar a experiência suspensa. Colocar no resultado final vivências da realização: contar o que não funcionou, situações que se pretendia fazer e não fez, atitudes tomadas e consideradas equivocadas, enfim, dividir com o leitor o work in progress.

Ismail Xavier, no livro $O$ discurso cinematográfico (2008), diferencia duas posturas artísticas no cinema: aquela que esconde que se trata de uma produção e aquela que coloca em jogo o dispositivo cinematográfico. Dispositivo, conforme esclarece Xavier, pode ser compreendido como o aparato tecnológico e econômico do cinema.

\footnotetext{
Quando o 'dispositivo' é ocultado, em favor de um ganho maior de ilusionismo, a operação se diz de transparência. Quando o 'dispositivo' é revelado ao espectador, possibilitando um ganho de distanciamento e crítica, a operação se diz de opacidade" (XAVIER, 2008, p. 6).
}

O cinema da transparência é a narrativa clássica hollywoodiana, que esconde o dispositivo e os artifícios de confecção da obra. É o filme que respeita uma lógica de continuidade e segue certa causalidade na relação dos eventos da trama. Já o cinema de opacidade surge com o cinema moderno, no pós-guerra. É a arte do fragmento, que deixa aparecer o dispositivo, expondo a técnica. É onde se encaixam os filmes mais críticos, mais inovadores, mais relacionados à poesia que ao espetáculo.

Pensemos com o documentário Doméstica, de Gabriel Mascaro (2011). O filme inicia em um quarto de menino, há um violão em cima da cama. Um adolescente de aproximadamente 16 anos entra no quadro e senta-se na cama. Olha diretamente para a câmera e se apresenta. Diz que recebeu a câmera para gravar sua empregada doméstica. Nesse caso, o diretor optou por apresentar, logo no início, suas estratégias: o dispositivo de enviar câmeras para adolescentes filmarem suas 
domésticas. Assim, há um compartilhamento com o espectador das regras do jogo, um esclarecimento do que será visto na tela e de que se trata de uma construção.

Imagem 6. Cena do filme Doméstica, 2011

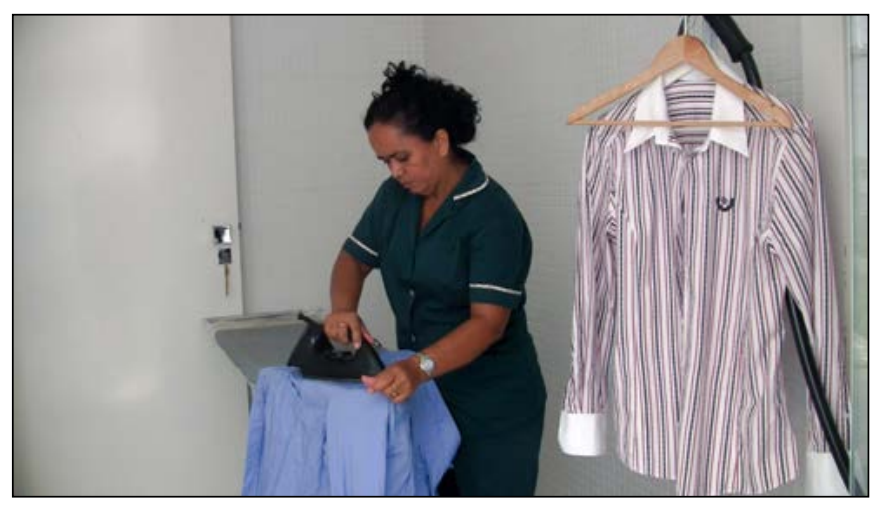

Fonte: https://sempreumfilme.wordpress.com.

Um filme aproxima-se da ação política quando faz do dispositivo não apenas um jogo de dominação, mas de abertura à participação, ao compartilhar seus modos de produção. Como transpor essa prática de compartilhamento para as pesquisas atuais em educação? Como podemos, bem como Moreira Salles em Santiago e como Mascaro em Doméstica, compartilhar nossa experiência, expor nossa maneira singular de pesquisar, fazendo dessa atitude, também, um gesto criativo? Qual a potência de nos colocarmos enquanto aprendizes no mundo e não detentores de verdades?

\section{Para fechar, uma abertura}

Se a arte pode nos desacomodar, ao mostrar imagens de composições que ainda são menos usuais na ordem do dia, isso pode servir para nós - pesquisadores - como um chamado a empreender essa ética de invenção também em nossos textos. Fazer da experiência uma marca singular de expressão, e também um gesto inventivo. Para isso, mas vale ver a pesquisa como algo prazeroso, que nos preenche, nos envolve, do que vê-la simplesmente como obrigação.

O que aqui foi posto, foi pensado como relações de vizinhança entre arte e pesquisa, posto que método cada pesquisador enxerga e inventa o seu. "Talvez só concebamos bem o que tivermos inventado" (VALERY, 1998, p. 205). É no movimento que vamos descobrindo nossas formas de criar, e um modo singular de artesania para a confecção de nossas pesquisas.

Nossa proposta, com esse artigo, é incentivar pesquisadores a relacionar sua escrita com a montagem cinematográfica, com a escolha de palavras para um poema ou com uma composição musical - enfim: delirar, viajar mantendo-se no lugar. Fazer do texto algo que possa ser lido por sujeitos de tipos heterogêneos 
e não só por leitores iniciados em determinadas teorias - um texto que vibre, que pare em pé sozinho.

Assim, a obra se cruza com a vida. O pesquisador, não menos que o artista, mergulha fundo em seu processo. Age com seu desejo que, na escrita, é criação de mundo (ROLNIK, 2014, p. 56). Aproximar os estudos dos amores: o trabalho é mais potente quando roça com nossas inquietações pessoais e profissionais. Desse jeito, todo trabalho tem algo de visceral do próprio autor.

Fazer pesquisa, seja nas artes, na educação ou em qualquer outro campo de conhecimento, é fazer ciência. Nosso apego ao senso comum nos leva a olhar diretamente para o rótulo de "dureza" - necessidade de certezas e afirmações - do campo científico. Vemos, muitas vezes, a pesquisa como uma atitude de descobrir e definir dados e conceitos. Aqui, buscamos reforçar o que muito já vem sendo dito e pensado, que, para além do rigor científico que nos cabe, nós pesquisadores ainda podemos inventar, experimentar - deixar-se levar pelo fluxo da experiência.

Sete pistas, sete rastros, sete pensamentos sobre pontos que nos interessam pensar nessa contemporaneidade. A questão da alteridade abre o texto, por tratarmos como uma das mais relevantes, no sentido de colocar no horizonte das pesquisas uma postura ética, não só consigo, mas com aqueles com quem dialogamos durante o caminho. A disposição para uma escrita fabulatória, inventiva, pode nos ajudar a dizer sobre a temática, variando os modos usuais de expressão. Criar personagens, misturar elementos heterogêneos, fazer ficção é também um modo de encarar a impossibilidade de acessar a verdade, pelo menos uma verdade absoluta.

Nesse jogo de pensamento e escrita, ao se colocar no texto, entregar-se, o pesquisador fabrica um estilo. Estilo, retomando o que foi dito na terceira pista, é não só fazer surgir um modo peculiar de se expressar, como traçar relações e cruzamentos inventivos, entre matérias de diferentes naturezas. E nessa montagem, a engrenagem é por si só agenciamento. Se tudo a nossa volta são máquinas em variação constante, e se nós mesmos somos máquinas, ora desejantes ora reprodutoras de clichês, por que não tomar consciência de nosso poder de agenciar forças, e fazer da escrita um labor artístico?

Falar em processualidade é sobretudo falar em deixar-se levar pelo que vai ocorrendo no caminho, sem tanta pré-definição do que precisa ser encontrado. Não requer descortinar verdades ou desvendar teses, mas sim viver processos, deixandose afetar por aquilo que nem esperávamos encontrar no movimento da pesquisa. E, quem sabe, não nos motivamos para, depois de toda essa experiência - que porta consigo angústias, momentos de indefinições, dúvidas, momentos alegres, insights, gritos de alegria e de desespero - contar um pouco dessa trajetória percorrida, com suas falhas e segredos, compartilhando com o leitor a maquinaria de um pesquisar singular, e que porte, por conta disso, vida. 


\section{REFERÊNCIAS}

BERGALA, Alain. Abbas Kiarostami. Paris: Sceren---CNDP. Cahiers du Cinéma (Les petits cahiers), 2004.

BROOK, Peter. Não há segredos. Reflexões sobre atuação e teatro. São Paulo: Via Letras, 2016.

COMOLLI, Jean-Louis. Ver e Poder. A inocência perdida: cinema, televisão, ficção, documentário. Belo Horizonte: Editora UFMG, 2008.

DELEUZE, Gilles; GUATTARI, Félix. Kafka: por uma literatura menor. Rio de Janeiro: Imago editora LTDA, 1977.

DELEUZE, Gilles; PARNET, Claire. L’ Abécédaire de Gilles Deleuze. Entrevista com Gilles Deleuze. Editoração: Brasil, Ministério de Educação, “TV Escola”, 2001. Paris:

Editions Montparnasse, 1997. 1 videocassete, VHS, son., color.

DELEUZE, Gilles. A imagem-tempo. Tradução de Eloisa de Araujo Ribeiro. São Paulo: Brasiliense, 2005.

DELEUZE, Gilles; GUATTARI, Félix. O que é a filosofia? São Paulo: Editora 34, 2010.

DELEUZE, Gilles. Dois regimes de loucos. Textos e entrevistas (1975-1995). São Paulo: Editora 34, 2016.

KIAROSTAMI, Abbas. Abbas Kiarostami: duas ou três coisas que sei de mim. São Paulo: Cosac Naify, 2013.

LISPECTOR, Clarice. Todos os contos. Rio de Janeiro: Rocco, 2016.

RANCIÈRE, Jacques. A partilha do sensível: estética e política. São Paulo: EXO experimental org.; Editora 34, 2009.

ROLNIK, Suely. Cartografia Sentimental: transformações contemporâneas do desejo. Porto Alegre: Sulina; Editora da UFRGS, 2014.

VALÉRY, Paul. Introdução ao método de Leonardo da Vinci. São Paulo: Ed. 34, 1998.

WENDERS, Wim. Dos discursos para Pina Bausch. In: __. Los pixels de Cézanne y otras impresiones sobre mis afinidades artísticas. Buenos Aires: Caja Negra, 2016, p. 103-128.

\section{FILMES CITADOS}

DEZ. Direção: Abbas Kiarostami. Irã, 2002. 1 DVD (88 min).

DOMÉSTICA. Direção: Gabriel Mascaro. Vitrine Filmes, Brasil, 2011. 1 DVD (76 min). 
E A VIDA continua. Direção: Abbas Kiarostami. Irã, 1992. 1 DVD (108 min).

JOGO de Cena, Eduardo Coutinho. VideoFilmes, Brasil, 2007. 1 DVD (105 min).

ONDE fica a casa do meu amigo. Direção: Abbas Kiarostami. Irã, 1987. 1 DVD (87 $\min )$.

PAULINHO da Viola - meu tempo é hoje. Direção: Izabel Jaguaribe. Bretz Filmes, Brasil, 2003. 1 DVD (83 min).

PINA. Direção: Wim Wenders. Imovision, 2011. 1 DVD (103 min).

SANTIAGO. Direção: João Moreira Salles. VideoFilmes, Brasil, 2007. 1 DVD (80 min). 